\title{
Unifying Biology
}




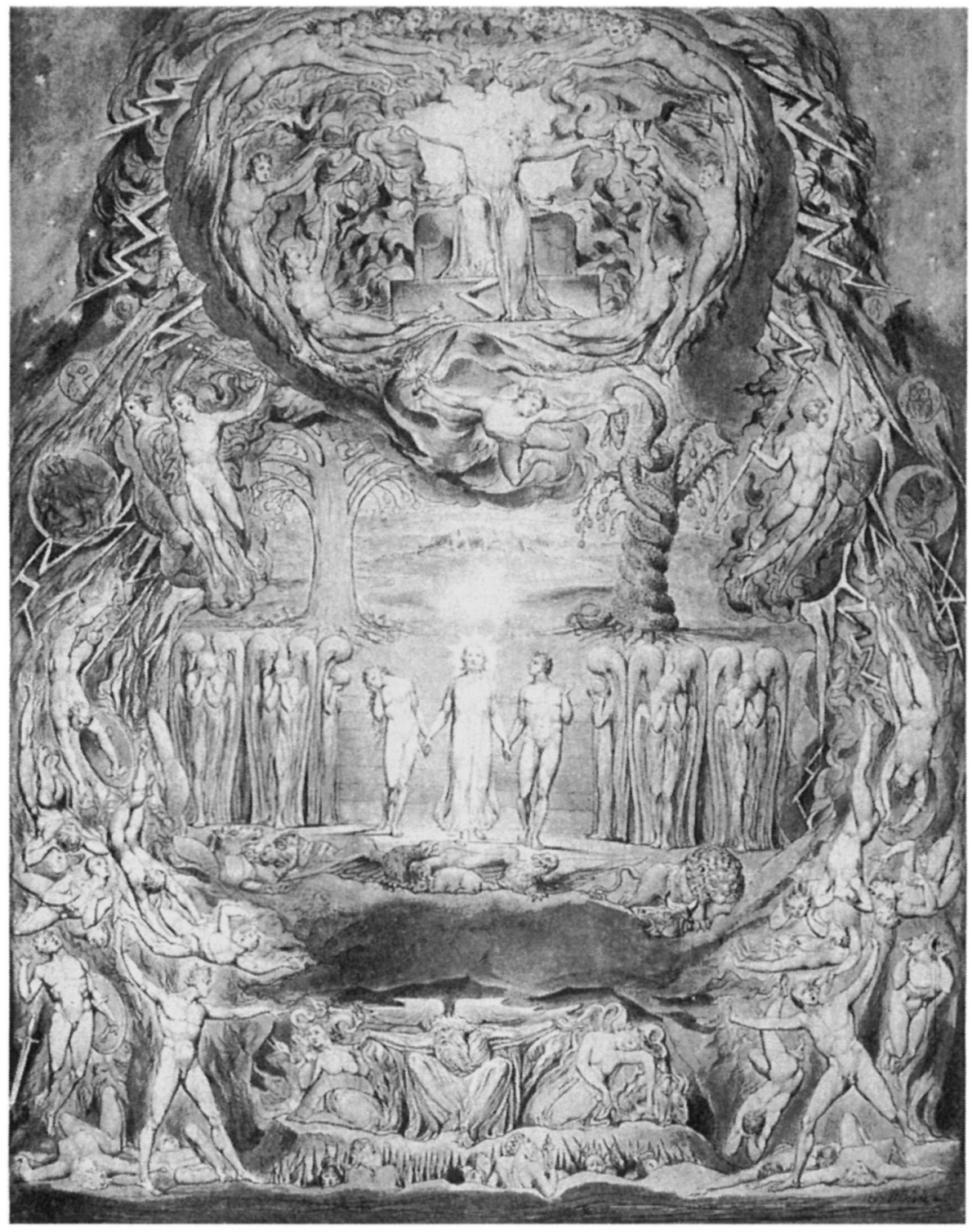

FrontisPiece: William Blake, Fall of Man, watercolor, 1807. Courtesy of the Trustees of the Victoria and Albert Museum. 


\section{Unifying Biology}

THE EVOLUTIONARY SYNTHESIS AND

EVOLUTIONARY BIOLOGY

Vassiliki Betty Smocovitis 
Copyright (C) 1996 by Princeton University Press

Published by Princeton University Press, 41 William Street,

Princeton, New Jersey $\mathbf{0 8 5 4 0}$

In the United Kingdom: Princeton University Press,

Chichester, West Sussex

All Rights Reserved

Library of Congress Cataloging-in-Publication Data

Smocovitis, Vassiliki Betty.

Unifying biology : the evolutionary synthesis and evolutionary biology / Vassiliki Betty Smocovitis.

p. $\quad \mathrm{cm}$.

Includes bibliographical references and index.

ISBN 0-691-03343-9 (cloth : alk. paper)

1. Evolution (Biology)-History.

2. Biology-History. I. Title.

QH361.S64 1996

$575^{\prime} .009-\mathrm{dc} 20 \quad 96-5605$

This book has been composed in Galliard

Princeton University Press books are printed on acid-free paper and meet the guidelines for permanence and durability of the Committee on Production

Guidelines for Book Longevity of the

Council on Library Resources

Printed in the United States of America

by Princeton Academic Press

10987654321 
To Ernst Mayr and William B. Provine 

His father studied him for a long time in bewilderment before saying, "For this you want to sacrifice your future? The origin of life and its destiny? The origin of life was Adam, and our destiny is paradise and hellfire. Or has there been some new discovery concerning this?"

Naguib Mahfouz, The Palace of Desire, The Cairo Trilogy II

The doors of heaven and hell are adjacent and identical.

Nikos Kazantzakis, The Last Temptation of Christ 
